\title{
INFLUENCE OF COUNSELLING SERVICES ON NON TEACHING STAFF PERFORMANCE IN PUBLIC UNIVERSITIES OF NAKURU COUNTY, KENYA
}

\author{
Phiona J. Kipkorir \\ Egerton University (Administration Division), Keny \\ phionajerop@yahoo.com \\ David Gichuhi \\ School of Entrepreneurship, Procurement \& Management \\ Jomo Kenyatta University of Agriculture and Technology, Kenya
}

\begin{abstract}
Employees are the most important human resource an organization cannot do without. They make a significant contribution to the success of an organization. Currently there is increased pressure for employees to be productive at their work place. This pressure is presented by the need to deliver the expected product or service in the market place while fulfilling the organization's mission and vision. Most employees suffer from a number of personal issues such as emotional, family and home life conflicts, mental health concerns, substance abuse problems, and other health disorders that if not attended to has the capability of negatively influencing on their effective performance. The purpose of the study was to assess the influence of counselling services on non teaching staff performance. The study was guided by person centred theory. The target population comprised administrative staff. Purposive sampling was used to select the administrators in public universities of Nakuru county. Census was used to get a sample size of 91 respondents. A structured questionnaire was administered to provide the required data. The questionnaire was pilot tested to ascertain its validity and reliability. Reliability coefficient of 0.733 was found and considered reliable. The study employed both descriptive and inferential statistics to present and analyze the data Statistical Package for Social Science (SPSS) version 22 a computer program for windows aided in data analysis. The findings of the study revealed that there that there was a moderate statistically significant positive relationship of $(r=0.472, p<0.05)$ between Counselling services and Employee performance. Recommendations were that HR departments in public Universities needs to sensitize employees on the provision of counselling services. These services should also be designed to address employee needs and frequently offered as the need arises. . The study also recommends that further research could be carried out in other cadre of profession in both public and private universities to establish the differences.
\end{abstract}

Key words: Counselling, Employee Assistance Programs, Employee Performance, Nakuru County.

\section{Council for Innovative Research}

Peer Review Research Publishing System

\section{Journal: International Journal Of Management \& Information Technology}

Vol . 10, No 9

editorsijmit@gmail.com

www.ijmit.com 


\subsection{Background of the Study}

Employee Assistance Program (EAP) is widely used to identify services that address the employee problems in the workplace. EAPs are an employer sponsored benefit consisting of diagnostic and referral services for employees and their families. According to Newton, Hayday and Barkworth (2005) EAP is a worksite program intended to assist in the identification and resolution of employee concerns which affect or may affect work performance. The EAP is an intervention designed to provide professional services to employees whose job performance is affected negatively by work concerns and personal problems. EAPs assist employee in identifying and resolving personal concerns including health, marital, family, financial, alcohol, drug, legal, emotional, stress or other personal issues that may affect job performance (Employee Assistance Professionals Association (EAPA, 2010c).

Counselling is the act of assisting a client to have a positive perception about things. It aims to assist the client to possibly perceive things from a different point of view from what the initially perceive it, to enable the client function effectively. Counselling enables a client to develop positive feelings, experiences and behaviours that would facilitate positive change. Counselling services are offered to the person that is undergoing a problem and deserves professional assistance to enable him overcome such problem (Roy, 2011). She argues that such a problem could keep the individual disturbed and under tension unless resolved, the development of this individual will continue to be hampered. Counselling therefore is a specialized service carried out by professionals or trained personnel in personality development and in the act of handling exceptional individuals or groups. Counselling is a process involving two individuals, one seeking assistance and the other a professionally trained person to help solve problems of a client to orient and direct him towards a goal, which leads to his maximum development and growth.

Counselling services are therefore required for individuals having developmental problems because of the handicap they suffer in any area of emotional either because of hereditary factors or environment conditions. When an employee's performance or that of the work group is affected by personal problems, the employer, supervisor or manager must intervene. In such cases referral to professional counselling may be appropriate. An analysis of counselling at work and its associated activities has found a range of benefits to individual employees and the organization. There is positive correlation between the provision of counselling and workplace benefits that impact on employee job performance. (McLeod, 2001).

Most people feel depressed when they experience a breakdown in their relationships or suffer disappointment and when the pressures of work or family life build up as well as anxiety (Lynch, 1998). Giving EAP services for employees experiencing these problems is an important benefit and can enhance the image of the organization to its employees. EAP therefore has a direct impact on the level of employee satisfaction and thus on the value an employee can produce in the organization. This enables employees to serve organization customers and increase their increasing loyalty towards the organization.

EAPs are employer sponsored programs designed to alleviate a range of workplace problems using core technologies such as screening, assessment, brief intervention and referral to service providers, case management and follow-up services for mental health and substance-abuse problems. There has been a significant increase in organization investment in employee wellbeing resulting from the EAP. Attridge (2010) indicates that a number of studies have shown positive outcomes for EAPs in different areas especially in the workplace performance and benefit cost categories.

EAP refer clients to individuals or organizations that offer professional support, advice and treatment in various fields of relevance that match best with the client needs. The EAP has procedures to facilitate client referrals, which address the provision of consultation between the EAP and the host or customer organization, and responsibilities for providing followup, aftercare, and transition for clients served. According to McLeod (2001) counselling provides a supportive service to clients and employees in the workplace, developments that help alleviate symptoms of ill behaviour which manifest themselves in the form of conflicts, bullying and undermining of unsuitable work conditions or bad relationships with colleagues. Cole (2003) states that workplace counselling opens up communication between staff and employers, and encourages frank discussions. Counselling enables workers to explore alternative solutions to the problems with greater health and well-being resulting in better work performance.

Personal problems may cause the organization a lot in terms of productivity. According to Oher (1999), solving personal problems, retains quality staff, giving management greater knowledge of employees and how satisfied they are. This results in improved staff morale, efficiency, absenteeism and turnover thereby reducing grievances. McLeod (2001) argues that employees who receive counselling at their workplace experience increased productivity as compared to those who did not practice workplace counselling. Mayor (2006) found that workplace counselling can achieve reduction in work related stress in more that 50 per cent of employees who have received counselling. Workplace counselling assists employees to reduce work related stress as well as socioeconomic stresses or pressures (Tehran, 1997). He found out that work related stress had decreased by a larger percentage and this was shown by work performance that had increased by 50 per cent. In addition, he suggests that employee management relationship also improved within the organization thus made an impact on the productivity level.

There is a positive link between counselling employees and personnel performance. Stresses that affect employees were caused by sickness and led to absence from work. This was a major contributor to poor work performance (Highley, 1996). McLeod (2008) found out that employees have to be aware of all workplace counselling policies and practices for easy evaluation. According to the research, 80 per cent of those who were aware of these policies and practices were able to recommend or use counselling again. McInnes (2007) found out that wellbeing and personal development by employees is better approached when they are all informed. This gives employees to produce better results when all 
participants are informed of their existence and rationale. This gives employees a better understanding and appreciation of workplace.

Workplace counselling is important in improving employee well being and performance. It also helps employees in alleviating symptoms of workplace stress, burnout and depression. Workplace counselling should be used as a tool to restore employees and potentially improve employee and organizational performance (Chan, 2011)Workplace counselling has a significant effect on employees. This increases job performance in an organization (Izzat, 2014). A study on evaluating the workplace influenceof counselling by David, John and Richard (2012) revealed that workplace counselling resulted in a positive impact on the workplace. According to Munyolo (2015) in his study on the role of EAP on employee productivity he concluded that there was a relationship between use of EAPs and productivity. He noted that with an increase in EAPs, employees are motivated and therefore increasing their productivity.

\subsection{Statement of the Problem}

Most organizations realize that job performance of workers seems to be declining. This is because most workers exhibit negative attitude towards their jobs. According to Zetlin (2013) personal problems sometimes affect their work performance. Personal challenge causes absenteeism and makes it difficult for employees to concentrate on their jobs. There is an increased pressure for employees to be productive at their work place. This pressure is presented by the need to deliver the expected product or service in the market place while fulfilling the organization's mission (Beard, 2000). It has been reported that employees suffer from a number of issues such as emotional, family and home life conflicts, mental health concerns, substance abuse problems, and other health disorders that if not attended to has the capability of negatively influencing on their effective performance (The Hartford, 2007). Minimal attention has been given towards ensuring workers in public universities have been provided with the necessary resources, motivation, effective job allocation measures and management (Waswa and Swaleh, 2012). Additionally Owino et al (2013) argues that lack of resources, motivation, and negative relationships leads to stressed employees and poor performance. Public Universities in their strategic plans have indicated provision of Employee Assistance services. Despite these provisions some of non teaching staff performance does not meet the required standard. This study therefore seeks to assess the influence of counselling services on non teaching staff performance in public Universities of Nakuru County.

\subsection{Purpose and Objective of the Study}

To establish the influence of counselling services on non teaching staff performance in public Universities of Nakuru County, Kenya.

\subsection{Research Question}

What are the influenceof counselling services on non teaching staff performance in public County, Kenya?

\subsection{LITERATURE REVIEW}

\subsection{THEORETICAL REVIEW}

This study was guided by Person Centered Theory

\subsubsection{Person Centered Theory}

Person Centered Theory is also known as Client Centred Theory was developed by Carl Rodgers in the 1940s. Rather than viewing people as inherently flawed with problematic behaviors and thoughts that require treatment, person centered therapy identifies that each person has the capacity and desire for personal growth and change. Rogers termed this natural human inclination "actualizing tendency," or self actualization. He likened it to the way that other living organisms strive toward balance, order, and greater complexity. According to Rogers (1957) individuals have within themselves vast resources for self understanding and for altering their self concepts, basic attitudes, and self directed behaviour. These resources can be tapped if a definable climate of facilitative psychological attitudes can be provided. The theory is guided by three principles namely:

\section{(i)Unconditional positive regard}

The clients' experiences, positive or negative, should be accepted by the therapist without any conditions or judgment. In this way, the client can share experiences without fear of being judged. Corey (2009) suggests that a therapist needs to communicate with deep and genuine caring for the client as a person. He further states that caring should be unconditional and the client should not be judged by feelings, thoughts and behaviour.

\section{(ii)Accurate empathetic understanding}

Empathy is the ability to understand what the client is feeling. This refers to the therapist's ability to understand sensitively and accurately but not sympathetically the client's experience and feelings in the here and now. An important part of the task of the person centered counsellor is to follow precisely what the client is feeling and to communicate to them that the therapist understands what they are feeling. 


\section{(iii) Congruence}

Congruence is also called genuineness. Congruence is the most important attribute in counselling according to Rogers. This means that, unlike the psychodynamic therapist who generally maintains a 'blank screen' and reveals little of their own personality in therapy, the Rogerian is keen to allow the client to experience them as they really are. The therapist does not have a façade (like psychoanalysis), that is, the therapist's internal and external experiences are one in the same. In short, the therapist is authentic. Gurman and Messer (2003) states that therapists should be genuine during the therapy hour. Therapists needs to openly express their feelings and reactions throughout the session. Thus if the therapists are genuine in their relationships with clients then the trust will be generated and the process of therapy will get underway.

\subsubsection{Counselling Services and Employee Performance}

Counselling is the act of assisting a client to have a positive perception about things. It aims to assist the client to possibly perceive things from a different point of view from what they initially perceive it to enable the client function effectively. Gichinga (2011) defines counselling as a relationship in which one person helps another to understand and solve their problems the ultimate goal is a helping relationship. Employee counselling can be defined as a process which is initiated by the counsellor or the manager to assist the employee or subordinate to gain knowledge, understanding and insights on a performance concern. This could relate to the counsellee's attitude, motivation or interpersonal skills. Workplace counselling is the provision of brief psychological therapy for employees of an organization paid for by the employer. Workplace counselling offers employees a facility that is confidential, easily accessed, provides a properly qualified and supervised practitioner, and promises to alleviate distress within a reasonably short period of time.

Workplace counselling enables the employer to give a service that is valued by employees and has the potential for savings by reducing sickness absence, takes pressure off managers through the availability of a constructive means of dealing with 'difficult' staff or situations, and contributes to its reputation as a caring employer. Essentially the aim of counselling is to provide timely professional and confidential aid for employees whose personal problems might otherwise lead to work impairment, absenteeism, reduce productivity and cause accidents and conflicts in the workplace, or even job termination.

Counselling enables a client to develop positive feelings, experiences and behaviours that would facilitate positive change. Roy (2011) agrees that counselling services are offered to the person that is undergoing a problem and deserves professional assistance to enable him overcome such problem. She argues that such a problem could keep the individual disturbed and under tension unless resolved, the development of this individual will continue to be hampered.

Counselling is seen as encompassing the full range of personalized assistance given to the individual seeking to expand his self understanding and his understanding of others (Odeburumi, 2002). The EAP counselling component is seen as the primary intervention and so is the subject of most EAP related research (Attridge, 2009). Previous research has shown that EAP counselling client satisfaction is generally around $95 \%$ and measured improvements in employee absenteeism, productivity and identified a positive impact on workers compensation costs (McLeod, 2001).

Counselling and psychological support for employees is the basis of any human organization. Modalities of counselling services include telephone counselling, face to face counselling, psychological debriefing, group support and legal advice. The importance of this is to support staff through any difficulties that impact on their working lives. Core to the service is the ability to work with organizations and their staff at all levels. Performance counselling is an indispensable part of job supervision in any organization if employees must be efficient in their performance.

Employee counselling programs are beneficial to solving employee problems that affect job performance. Counselling programs were initially designed to address drug and alcohol problems among employees, but their role has expanded over the years to meet more employee's needs. Such employees' needs addressed by these counselling programs include marriage and family problems, financial problems, legal problems, stress, anxiety, depression, and other emotional disturbances. Modern counselling services cover employees and their families such that, issues arising from both work and home environments are addressed. The provision of workplace counselling has steadily expanded over the years, with more than $75 \%$ of medium and large organizations in Britain and North America making counselling available to their staff (Carroll \& Walton, 1999; Oher, 1999)

Employee counselling programs according to Richard, Emener, and Hutchison (2009) have the ability to enhance efficiency and effectiveness of employees' work. Therefore increased work efficiency and effectiveness results to high productivity and improved performance in an organization. Employee counselling programs according to Gupton et.al (2011), relieves negative behavioural attributes such as anger, violence, substance abuse, absenteeism, attendance at work and work related accidents that impact negatively on job performance. One of the many reasons for adopting employee counselling programs in any organization is to mitigate employee's personal problems that affect their job performance. Implementation of the counselling programs is one of the positive ways of managing the lives and performance of employee. According to Zarkin and Garfinkel (1994), organizations that value its employees will provide counselling programs to improve job performance, enhance productivity, and protect its investments.

According to Rajin (2012) the role of EAPs is to motivate employees to seek help before their personal problems reach a chronic stage that reduces the employee's ability to perform their job well, to retain valued employees, restore employee's productivity and to enable them to lead a meaningful and happy life while they are in the workplace. 


\subsection{Conceptual Framework}

\begin{tabular}{|c|c|}
\hline $\begin{array}{l}\text { Counselling services } \\
\begin{array}{l}\text { - Relationship problems } \\
\text { - Defining problems } \\
\text { - Solving problems }\end{array}\end{array}$ & $\begin{array}{c}\text { Employee Performance } \\
\text { - Achieving targets }\end{array}$ \\
\hline Independent Variable & Dependent Variable \\
\hline
\end{tabular}

Figure1: Conceptual Framework

\subsection{RESEARCH METHODOLOGY}

\subsection{Research Design}

The study adopted a descriptive research design. The design was ideal for this study because the researcher conducted a study of facts as they were at the time of the study (Frankel \& Wallen, 2000). According to Orodho (2003) descriptive research describes the nature of existing conditions, identifies the standards against which existing conditions can be compared and determine the relationship that exists between the specific events. Mugenda and Mugenda (2003) defines target population as that population whose research and findings are used to generalize to the entire population. The target population was the Public Universities non teaching staff in Nakuru County. The study used purposive sampling technique to select administrators in public universities. The validity and reliability of the research instrument was pilot tested to ascertain the validity and reliability. This research used both quantitative and qualitative methods. Qualitative helps to understand people's perceptions while quantitative focuses on prediction. .

\subsection{Sample Size}

A sample of 91 employees was selected for this study from the target population. The study used census as advocated by (Israel ${ }^{2}, 1992$ ), that a census is attractive for small population of 200 or less. A census eliminates error and provides data on all the individuals in the population. Finally, the entire population was sampled to achieve a desirable level of precision.

\subsection{Data collection}

The structured questionnaire was used to collect the information from the employees of the universities at their work place. Questionnaires were circulated to 91 respondents who were Administrators in public Universities of Nakuru County. 76 (83.5\%) questionnaires were successfully completed and received while 15 $(16.5 \%)$ questionnaires were not returned Mugenda and Mugenda (2003) reported that $50 \%$ response is adequate, $60 \%$ good and above $70 \%$ rates as very good.

\subsection{Data Analysis}

Once the raw data had been collected, the first step was to clean the data for any inconsistencies. The coding of the data was the next step. Descriptive and inferential statistics were used to explain results of the findings. These included means, frequencies and percentages. Analysis was done using a computer programme, the Statistical Package for Social Sciences (SPSS). In addition, the researcher used Pearson correlation so as to determine the relationship between counseling services(independent variable) and employee performance (dependent variable).

\subsection{Results and Findings}

\subsubsection{Descriptive Statistics}

Descriptive statistical analysis was used to analyze counseling services. In reference scaling (Likert scale) used in the study design, 5 represented strongly agree, 4 represented agree, 3 represented Not sure, 2 represented disagree and 1 represented strongly disagree, therefore strongly disagree (1) was minimum, strongly agree (5) was maximum. The mean was analyzed based on the respondents choices scaled between strongly agree and strongly disagree as indicated in table 1 
Table 1: Elements of Counselling Services

\begin{tabular}{|c|c|c|c|c|}
\hline Elements of counselling services & Min & Max & Mean & Std. Dev. \\
\hline $\begin{array}{l}\text { Counselling plays an important role in solving employees' } \\
\text { problems }\end{array}$ & 2 & 5 & 4.38 & 0.711 \\
\hline Counselling helps employees in defining their problems & 2 & 5 & 4.14 & 0.605 \\
\hline Counselling helps employees in dealing with problems & 2 & 5 & 4.24 & 0.630 \\
\hline $\begin{array}{l}\text { Counselling enables employees to be more responsible towards } \\
\text { their duty at work }\end{array}$ & 2 & 5 & 3.91 & 0.882 \\
\hline $\begin{array}{l}\text { Counselling enables employees to adapt themselves with working } \\
\text { environment }\end{array}$ & 2 & 5 & 3.89 & 0.918 \\
\hline $\begin{array}{l}\text { Discussing personal problems with counsellor lightens the } \\
\text { pressure on the employees }\end{array}$ & 2 & 5 & 3.88 & 1.006 \\
\hline Counselling process takes a long time and it is boring & 1 & 5 & 2.36 & 1.163 \\
\hline I feel ashamed and shy to discuss my problems with counsellor & 1 & 5 & 2.79 & 1.135 \\
\hline $\begin{array}{l}\text { Counselling session helps me to know my weaknesses and } \\
\text { problems }\end{array}$ & 1 & 5 & 3.93 & 0.772 \\
\hline $\begin{array}{l}\text { Counselling is important in improving job satisfaction among the } \\
\text { employees }\end{array}$ & 1 & 5 & 3.79 & 0.957 \\
\hline Counselling helps us in developing self-improvement & 1 & 5 & 3.97 & 0.748 \\
\hline $\begin{array}{l}\text { Counselling service is one of the important facilities in }{ }^{a n} \\
\text { organization }\end{array}$ & 2 & 5 & 4.39 & 0.655 \\
\hline I think the counselling programs are waste of time and money & 1 & 4 & 1.43 & 0.596 \\
\hline Valid N (list wise) & & & & \\
\hline
\end{tabular}

According to the findings in table 4.2 it is evident that most of the respondents in this study agreed with most aspects of counselling services with a mean of 4 . The findings concur with to Richard, Emener, and Hutchison (2009) that counselling programs have the ability to enhance efficiency and effectiveness of employees' work. However the findings revealed that respondents disagreed that counselling process takes a long time and it is boring compared to those who strongly disagreed that counselling programs were waste of time and money represented by a mean of 2 and 1 respectively.

Table 2: Elements of Employee Performance

\begin{tabular}{|c|c|c|c|c|c|}
\hline Elements of employee performance & $\mathrm{N}$ & Min & Max & Mean & Std. Dev. \\
\hline I am satisfied with my performance at my work & 76 & 1 & 5 & 4.08 & 0.829 \\
\hline I fear about the quality of my work & 76 & 1 & 5 & 2.71 & 1.081 \\
\hline I work more than 8 hours & 76 & 1 & 5 & 3.39 & 1.173 \\
\hline I get tensed at non achievement of my target & 76 & 1 & 5 & 3.63 & 0.978 \\
\hline $\begin{array}{l}\text { I am able to plan and work in an organized manner whil } \\
\text { identifying priorities }\end{array}$ & $e_{76}$ & 2 & 5 & 4.05 & 0.943 \\
\hline $\begin{array}{l}\text { I am able to communicate effectively with customers and othe } \\
\text { colleagues }\end{array}$ & $r_{76}$ & 1 & 5 & 4.00 & 1.083 \\
\hline I am self-driven to undertake the agreed tasks & 76 & 1 & 5 & 4.35 & 0.830 \\
\hline I am careful in carrying out tasks or duties with proper attention & 76 & 2 & 5 & 4.29 & 0.689 \\
\hline Personal problems affects my job performance & 76 & 1 & 5 & 3.53 & 1.160 \\
\hline I respond to customers request promptly & 76 & 2 & 5 & 4.08 & 0.891 \\
\hline Valid N (list wise) & 76 & & & & \\
\hline
\end{tabular}

The analysis in table 4.5 above showed that the respondents agreed with most aspects of their performance with a mean of 4 . The respondents in the study were neutral whether they fear about the quality of their work and that they work more than 8 hours with a response mean of 3 . The findings revealed that employees were self driven to undertake the agreed tasks with the highest mean 4.35. This results is consistent with Rajin (2012) that EAPs motivates employee to seek help 
before their personal problems affects their productivity. The study also established that respondents were neutral about fearing the quality of work with lowest mean of 2.71 .

\subsection{Influence of Counselling Services on Non teaching Staff Performance in Public Universities of Nakuru County.}

The first objective of the study was to determine the influenceof counselling services on non teaching staff performance in public universities of Nakuru County. The key elements of Counselling services on non teaching staff performance in public universities of Nakuru County were: - Counselling plays an important role in solving employees' problems, counselling helps employees in defining their problems, counselling helps employees in dealing with problems, counselling enables employees to be more responsible towards their duty at work, counselling enables employees to adapt themselves with working environment, discussing personal problems with counsellor lightens the pressure on the employees, counselling process takes a long time and it is boring, employees feel ashamed and shy to discuss their problems with counsellor, counselling session helps employees to know their weaknesses and problems, employees think the counselling programs are waste of time and money, counselling helps employees in developing self-improvement, counselling service is one of the important facilities in an organization and is important in improving job satisfaction among the employees. The study used Pearson Correlation to establish the kind of relationship that existed between counselling services and employee performance.

Table 3: Correlation between Counselling Services and Employee Performance

\begin{tabular}{lll}
\hline & & Employee performance \\
\hline Counselling services & Pearson Correlation & 0.472 \\
& Sig. (1-tailed) & 0.000 \\
& $\mathrm{~N}$ & 76
\end{tabular}

${ }^{*}$ Correlation is significant at the 0.05 level (1-tailed).

Based on table 4.7 the results revealed that there was a moderate statistically significant positive relationship of $(r=0.472$, $p<0.05)$ between Counselling services and Employee performance. Consequently, this confirms the effect of counselling services on performance of non teaching staff in selected public universities of Nakuru County and answers the first research question that counselling services has significant influenceon the performance of non teaching Staff in public universities of Nakuru County.

The findings agree with Gishinga (2011) who sees counselling services aim is to provide timely professional and confidential aid for employees whose personal problems might otherwise lead to work impairment, absenteeism, reduce productivity and cause accidents and conflicts in the workplace, or even job termination. It is also supported by Izzat, (2014) who stated that counselling services increases job performance. These findings are consistent with studies done by Richard, Emener, and Hutchison (2009) who argued that counselling services have the ability to enhance efficiency and effectiveness of employees' work. Therefore increased work efficiency and effectiveness results to high productivity and improved performance in an organization.

\subsection{Summary}

The main objective of the study was to assess the Influence of counselling services on Non teaching Staff Performance in Public Universities of Nakuru County.

\subsection{Influence of Counselling Services on Non teaching Staff Performance in Public Universities of Nakuru County}

The objective of the study was to assess the Influence of counselling services on Non teaching Staff Performance in Public Universities in Nakuru County. Based on the findings first, it was established that non teaching staff in public Universities in Nakuru County acknowledged that Counselling services plays an important role in dealing with their problems and enabled them to be more responsible towards their duty at work, hence improving job satisfaction among the employees. Second, the study established that the counselling services is one of the important services in Public Universities. Counselling service offered in public Universities has moderate effect on Non teaching Staff Performance in Public Universities in Nakuru County. In general the results revealed that there is statistically significant positive relationship between counselling services and Non teaching Staff Performance in Public Universities indicated by moderate positive correlation of $47.2 \%$.

\subsection{Conclusion}

The main objective of the study was to assess the Influence of counselling services on Non teaching Staff Performance in Public Universities of Nakuru County. 


\subsubsection{Influence of Counselling Services on Non teaching Staff Performance in Public Universities of Nakuru County}

The study established that non teaching staff in public Universities of Nakuru County acknowledged that Counselling services plays an important role in dealing with their problems and enabled them to be more responsible towards their duty at work, hence improving job satisfaction among the employees. It can be concluded that counselling services is one of the important services in Public Universities and therefore important in improving non teaching staff performance.

\subsection{Recommendations}

\subsubsection{Policy Recommendations}

As indicated from the results of the study counselling services improve/enhance non teaching staff performance. It is recommended that employees should be sensitized on the availability of these services and accessibility to them.

It is also recommended that HR departments in public universities should be responsive to the needs and constantly changing requirements of the employees by designing EAPs suitable to the needs of the employees. Public universities need to establish an office with professionals who will be able to address specific needs of employees.

\subsubsection{Recommendations for Further Research}

This research was based on the influence Employee Assistance Programs on non teaching staff performance. The study focused on public universities only. This limits the generalization of results. Similar studies needs to be conducted in private universities. A comparative study can also be done to capture the Employee Assistance Programs adopted in public and private universities and their effect on staff performance and determine whether there is a difference in effect.

This research selectively captured non teaching staff only. A further research can be done to capture other cadre of profession in public universities such as the teaching staff and other support staff to establish whether the findings will be the same.

\section{REFERENCE}

1) Attridge, M. ( 2010). 20 Years of EAP cost research: taking the productivity path to ROI: this promising strategy can be accomplished with far fewer operational costs than traditional claims-based ROI studies and in far less time. The Journal of Employee Assistance, 40(4):8-11.

2) Attridge, M. (2005). The business case for the integration of employee assistance, work/life and wellness services: A literature review. Journal of Workplace

Behavioural Health,20(1), 31- 55

3) Beard, M. (2000). Organizational development: An EAP approach. Employee Assistance Quarterly, 16(1\&2), 117-140.

4) Chan, Y. K. (2011). How Effective is Workplace Counselling in Improving Employee Well- Being and Performance? Masters' Dissertations, School of Psychology. Leicester Research Archive, College of Medicine, Biological Sciences and Psychology. Retrieved December, 2014 from http://hdl.handle.net/2381/10904.

5) Cole, A. (2003). Counselling in the Workplace. Open University Press: Oxford.

6) Corey, G. (2009) Theory and Practice of Counselling and Psychotherapy Belmont: Thomson Brooks

7) David A. S., John P. \& Richard L. (2012). Evaluating the Workplace Effects of EAP Counselling. JHP, 6 (2).

8) Employee Assistance Professionals Association (EAPA). (2010c). What is an employee assistance program $(E A P)$ ? Arlington, VA: Author.

9) Frankel, J. K. \& Wallen, N. E. (2000). How to Design and Evaluate Research in Education $\quad\left(5^{\text {th }}\right.$ Ed). Boston: McGraw-Hill, Co.Inc.

10) Gichinga, E. M. (2011). Basic Counselling Skills. Nairobi: GEM Counselling services.

11) Greenberg, J. (2011). Behavior in Organizations. (10th ed.). England: Pearson Education Ltd

12) Gupton M. H., Axelrod E., Cornell L., Curran F. S.,Hood J. C., Kelly J., and Moss J.,( 2011), Support and Sustain: Psychological Intervention for Law Enforcement Personnel, The police chief, Vol. $78(8)$, page 92-97

13) Gurman, A.S., and Messer, S. B.(2003). Essential Psychotherapists Theory (2 ${ }^{\text {nd }}$ ed.). Essex: $\quad$ Pearson Longman Harlow

14) Highley, C. (1996). EAPs in the UK: evaluation, audit and the future. A Journal of Employee Counselling Today. Volume 8(1): 4-8 Labour Research Development,

(1994).Statistics

of Labour. Public Press: London

15) Humara, M. (2002). The relationship between anxiety and performance: A cognitive

behavioral perspective, Athletic Insight, 2, 1-11 


\section{ISSN 2278-5612}

16) Israel $^{2}$, D. G. (1992). Determining Sample Size ${ }^{1}$. Fact Sheet PEOD - 60. Florida Services, Institute of Food and Agricultural Sciences of Florida.

17) Izzat, F. (2O14) Significance of Workplace Counselling on Increasing from Job Performance organization in Malaysia. Retrieved https://www.academia.edu/2788038/ $\quad$ Significance

Cooperative Extension Counselling Increasing Job Performance in an Organization.

18) Kamau ,J. M (2013) Work-Life Balance Practices on Employee Job Performance at Eco Bank Kenya

19) Mayor, J., (2006). Occupational Wellbeing and Performance: a review of organisational health research. Australian Psychologist Journal, Volume 38(2):118-127

20) McLeod J. (2001) Counselling in the workplace: the facts. A systematic study of the research evidence. Rugby: BACP

21) McLeod, J. (2008). Research into the effectiveness of workplace counselling: new developments: Journal of counselling at work, winter Volume 9(2): 4-6

22) Mclnnes, B. (2007). Workplace Counselling: building an evidence base from practice. BACP

23) Mugenda, O., \& Mugenda,O., (2003). Research Methods (1st Ed). Nairobi: ACTS Publishers.

24) Munyolo,W.A. (2015) Role of Employee Assistance Programs (EAP) productivity within commercial Banks SubSector in Kenya.

25) Musyoka, M., Ogutu. M., \& Awino. Z., (2013), Employee stress and performance of listed in the Nairobi securities exchange: DBA Africa Management Review 2012, vol.3. No. 1 pp 115-129.

26) Newton, L, Hayday, S \& Barkworth, R. (2005). Employee assistance programmes.Brighton: Employment Studies.

27) Odeburumi, A. (2002). Understanding Guidance and Counselling. Abeokuta: Sopipo Press.

28) O'Donnell, M., (2009). Definition of health promotion. Embracing passion, enhancing

29) Oher, J.M. (1999). The Employee Assistance Handbook. Wiley: New York.

30) Orodho, J. (2003) Essentials of Educational and social sciences research methods: and Quantitative Approaches. Nairobi: ACTS press.

companies

Institute of

1) Owino, G.et al (2011), Role of institutional managers in quality assurance: reflections on Kenya's University education: Australian Journal of Business and Management Research. Vol.1 No.2

32) Rajin J., (2012), Employee assistance program in the South Africa police service: A case study of Moroka police station, Information about the functioning of EAP, page 45-57

33) Richard M. A., Emener W. G., Hutchison W. S., (2009). Employee assistance programs for school teachers and school personnel, ( $4^{\text {th }}$ ed.), Springfield, U.S, Charles C. Thomas publisher, page 354 - 359

34) Rogers, Carl R. (1957). The Necessary and Sufficient Conditions of Therapeutic Personality Journal of Consulting Psychology, 21. Retrieved from http://www.shoreline.edu/dchris/psych236/Documents/Rogers.pdf

35) Roy, M. (2011). Guidance and Counselling What is Counselling? Meaning, Need and Significance. Retrieved October 2014 from http://teacher education guidance and counsellin.blogspot.com/2011/03/what is counselling meaning need and.html.

36) Tehrani, N. (1997). Employee Welfare Services. BACP: Rugby

37) The Hartford. (2007). Healthier, more productive employees: A report on the real potential of employee assistance programs (EAP). Hartford, CT: Author.

38) Torjman, S. (2004).Culture and recreation: Links to well-being Ottawa: Caledon Institute of Social Policy.

39) Waswa F. \& Swaleh S. (2012), Faculty opinions on emerging corporatization in public Universities in Kenya. Education and General Studies Vol. 1(1) pp. 009-015

40) Zetlin, M. (2013). When Trouble at Home Becomes Trouble in the Office. Retrieved December 12th, 2014 from http://www.inc.com/minda-zetlin/employee-facing- personal-problems-heres-what-to-do.html International Journal of Research in Management and Social Sciences ISSN:2411-6629,Vol.1, No. 1, May 2015pp.1-11 